\title{
Choice for host-specific high-adhesive Lactobacillus strains
}

\author{
Xueyan Lin, Zhonghua Wang*, Zhongxiang Niu*, Hongjie Liu, Yun Wang
}

College of Animal Science and Technology, Shandong Agricultural University, Tai'an, China

Email: "zxniu@sdau.edu.cn, ${ }^{*}$ zhwang@,sdau.edu.cn

Received 18 January 2012; revised 26 February 2012; accepted 5 March 2012

\begin{abstract}
Adhesive ability was tested in seven lactobacillus solated from the chicken digestive tract after cultivation with CaCo-2 cells (intestinal epithelial cells), MDCK (dog kidney) cells and CEF (chicken embryo fiber) cells. We noted the following important observations regarding the adhesive ability between different lactobacillus strains and three cell types: the adhesive interaction between the $\mathrm{SDnB}_{7}, \mathrm{SDnE}_{1}$ and $\mathrm{SDnA}_{3}$ lactobacillus strains and $\mathrm{CaCo}-2$ cells was greater compared to controls, the adhesive effect between $\mathrm{SDnB}_{1}$ and CEF cells was also greater than controls and lactobacillus showed only minimal adherence to MDCK cells. Incubation time also affected lactobacillus adherence to CaCo- 2 cells: adhesive ability was optimal at $37^{\circ} \mathrm{C}$ when incubated for 2 days and this was confirmed by a local increase in the concentration of lactobacillus around $\mathrm{CaCo}-2$ cells when incubated for $24 \mathrm{~h}$ as opposed to $3 \mathrm{~h}$. Adherence ability in lactobacillus was also tested at various concentrations $\left(10^{8}, 10^{7}, 10^{6}, 10^{5}\right.$ and $\left.10^{4}\right)$. The number of lactobacillus that adhered around the cells was significantly increased in the treatment with $10^{8}$ bacterial cells. Transmission electron microscopy revealed that the cellularity of the junction between $\mathrm{CaCo}-2$ cells and lactobacillus was not compromised. Transmission electron microscopy also revealed that the thalli fabric structure remained intact
\end{abstract}

Keywords: Host Specific; CaCo-2 Cells; MDCK Cells; CEF Cells; High Adhesion Lactobacillus

\section{INTRODUCTION}

The definition for probiotics has gradually changed with an increasing understanding of how it influences human and animal health. A potentially successful probiotic strain is expected to have several desirable properties in order to show benefit. These properties include the ability to adhere to cells while remaining non-pathogenic. Adherence to the intestinal mucosa is considered selec-

${ }^{*}$ Corresponding authors. tion criteria for probiotic microorganisms [1-11].

Lactobacillus bacteria have the capacity to adhere to intestinal epithelial cells. Different species of these bacterium vary in their adherence ability. Rinkinen (2003) and Gusils (2002) suggested that the adhesive ability of probiotic strains is species specific but not host-specific $[12,13]$. We, on the other hand, aimed to demonstrate that strains were not only species-specific but also hostspecific.

We isolated lactobacillus bacteria from the chicken digestive tract and tested their adherence to $\mathrm{CaCo}-2$ cells, CEF cells and MDCK cells. The choice of high adhesive strains based on host-specificity will serve to advance research in adhesive mechanisms and production.

\section{MATERIALS AND METHODS}

\subsection{CaCo-2 Cells, MDCK Cells and CEF Cells}

$\mathrm{CaCo}-2$ cells (intestinal epithelial cells) were obtained from the cell bank, China science college, Shanghai. MDCK cells were obtained from the medical science college of Beijing. CEF cells were retrieved after 10 days from an SPF chicken embryo.

CaCo- 2 cell culture: $10 \%$ serum of new cattle DMEM culture liquids (penicillin, 100 ten thousands unit, streptomycin, $100 \mu \mathrm{g} / \mathrm{l})(\mathrm{pH} 7.0$ to 7.2$) ; 0.1 \mathrm{M}$ phosphate buffer ( $\mathrm{pH} 7.4)$; cell digestive liquids (0.02\% EDTA: D-Hanks liquids $=10: 1)$ (not included in $\mathrm{Ca}^{2+}, \mathrm{Mg}^{2+}$ ) When cells grew to a particular confluency we passaged them.

CEF cell culture: $5 \%$ serum of new cattle DMEM culture liquids (penicillin, 100 ten thousands unit, streptomycin, $100 \mu \mathrm{g} / \mathrm{l})(\mathrm{pH} 7.0$ to 7.2$) ; 0.1 \mathrm{M}$ phosphate buffer ( $\mathrm{pH} 7.4)$; cell digestive liquids $(0.02 \%$ EDTA: D-Hanks liquids $=10: 1)\left(\right.$ not included in $\left.\mathrm{Ca}^{2+}, \mathrm{Mg}^{2+}\right)$ When cells grew to a particular confluency we passaged them.

MDCK cell culture: $10 \%$ serum of new cattle DMEM culture liquids (penicillin, 100 ten thousands unit, streptomycin, $100 \mu \mathrm{g} / \mathrm{l})(\mathrm{pH} 7.0$ to 7.2$) ; 0.1 \mathrm{M}$ phosphate buffer ( $\mathrm{pH} 7.4)$; cell digestive liquids $(0.02 \%$ EDTA: D-Hanks liquids $=10: 1)$ (not included in $\mathrm{Ca}^{2+}, \mathrm{Mg}^{2+}$ ) When cells grew to a particular confluency we passaged 
them.

\subsection{Lactobacillus Strains}

Strains were provided by the microbiology teaching and researching room of Shandong agriculture university. For $\mathrm{SDnB}_{1}, \mathrm{SDnB}_{7}, \mathrm{SDnC}_{1}, \mathrm{SDnE}_{1}, \mathrm{SDnE}_{3}, \mathrm{SDnA}_{3}$ and $\mathrm{SDnA}_{4}$ (A, B, C and E, representative of crop, glandular stomach, small intestine and rectum, respectively) we used a $37^{\circ} \mathrm{C}$ incubation temperature (see $2 \mathrm{~d}$ and $4 \mathrm{~d}$ ).

\subsection{Lactobacillus Adherence Assay}

Briefly, cell monolayers were prepared on glass coverslips and then placed in 24-well corning tissue culture plates. For the various strains, we added liquids at a volume of $200 \mu \mathrm{l}$ and $400 \mu \mathrm{l}$ to the 24 -well plates (concentration of the strains was $1 \times 10^{8}$ bacteria per $\mathrm{ml} \mathrm{cul-}$ ture supernatants), incubated at $37^{\circ} \mathrm{C}$ in $5 \% \mathrm{CO}_{2}-95 \%$ air and after $3 \mathrm{~h}$ or $24 \mathrm{~h}$ of incubation, the glass was removed and the monolayers were washed six times with sterile PBS. After drying, fixation in methanol, and staining with a Gram stain, samples were examined microscopically. For each separate strain adherence assay, the number of adherent bacteria were evaluated in 20 random microscopic sections. Adhesion assays were evaluated by two different technicians to eliminate bias.

\subsection{Transmission Electrictron Microscopy}

We mixed CaCo-2 cell suspensions (at a concentration of $10^{5} / \mathrm{ml}$ ) with lactobacillus suspenstions (at a concentration of $10^{7} / \mathrm{ml}$ ), then incubated at $37^{\circ} \mathrm{C}$ in $5 \% \mathrm{CO}_{2}-95 \%$ air for $3 \mathrm{~h}$. Liquids were then collected, washed six times with sterile PBS and centrifuged (1000 rpm/min, $5 \mathrm{~min}$ ) to remove non-adherent bacteria. Cell were fixed with $3.5 \%$ glutaraldehyde and post-fixed with agar. Supernatant liquids were washed with $0.1 \mathrm{M}$ phosphate buffer for $1 \mathrm{~h}$, post-fixed with $1 \% \mathrm{O}_{\mathrm{S}} \mathrm{O}_{4}$, washed with $0.1 \mathrm{M}$ phosphate buffer and dehydrated in an alcohol gradient (30, 50, 70, 80, 90 and 100\% ethanol) suprr resin sock wrap up; LKB super film slicer have on film slice acetate shaddock-lemmon acid lead dye; the specimens were then examined with a JEOL-1200EX transmission electron microscope.

\section{RESULTS}

Lactobacillus strains are host-specific and the adhesion number between cell types is variable. The lactobacillus strains that successfully adhered to $\mathrm{CaCo}-2$ cells is shown in Figure 1 and Table 1. The effect of different lactobacillus strains adherence to $\mathrm{CaCo}-2$ cells is vaiable between $\mathrm{SDnB}_{1}, \mathrm{SDnB}_{7}$ and $\mathrm{SDnE}_{1}$, while $\mathrm{SDnA}_{3}$ had a significantly increased adhesive effect. Lactobacillus was shown to only slightly adhere to MDCK cells (Fig-

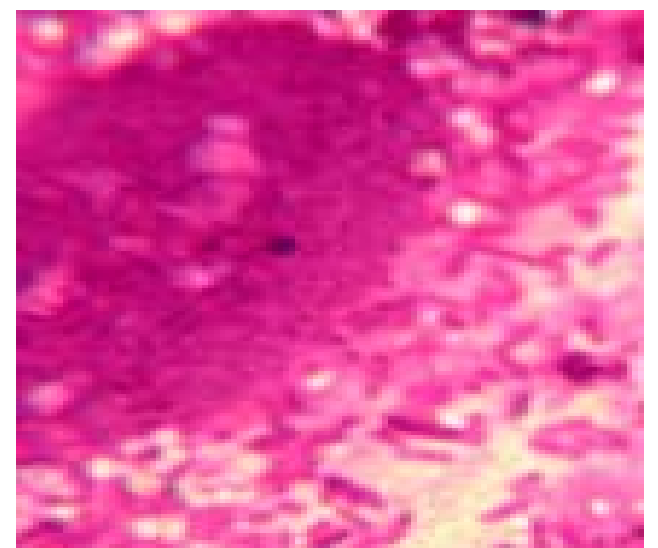

Figure 1. Lactobacillus adhere to $\mathrm{CaCo}-2$ cells.

Table 1. Various lactobacillus individual plants adhere to $\mathrm{CaCo}-$ 2 cells.

\begin{tabular}{ccc}
\hline $\begin{array}{c}\text { Individual } \\
\text { plants }\end{array}$ & Source & $\begin{array}{c}\text { Level of lactobacillus } \\
\text { adhere to CaCo-2 cell }\end{array}$ \\
\hline $\mathrm{SDnB}_{1}$ & $\begin{array}{c}\text { SPF chick } \\
\text { Glandular stomach } \\
\text { SPF chick }\end{array}$ & $11.10 \pm 0.78^{\mathrm{a}}$ \\
$\mathrm{SDnB}_{7}$ & $\begin{array}{c}\text { Glandular stomach } \\
\text { SPF chick } \\
\text { Small intestine } \\
\mathrm{SDnC}_{1}\end{array}$ & $20.00 \pm 1.46^{\mathrm{b}}$ \\
$\mathrm{SDnE}_{1}$ & $\begin{array}{c}\text { Chick rectum } \\
\mathrm{SDnA}_{3}\end{array}$ & $25.00 \pm 1.04^{\mathrm{c}}$ \\
\hline
\end{tabular}

a,b,c.d values within column with different superscripts differ significantly (p < $0.05)$.

ure 2). A number of Lactobacillus strains successfully adhere to CEF cells, in particular, the $\mathrm{SDnA}_{3}$ and $\mathrm{SDnB}_{1}$ strains demonstrated good adhesion (Figure 3, Table 2).

\subsection{Incubation Time Affects Lactobacillus Adhesion to CaCo-2 Cells}

Lactobacillus $\mathrm{SDnE}_{1}$ and $\mathrm{SDnB}_{7}$, when incubated at $37^{\circ} \mathrm{C}$ for $2 \mathrm{~d}$, demonstrated substantial adhesion ability (Tables 3 and 4).

\subsection{Concentration of Strains Affects Lactobacillus Adhesion to CaCo-2 Cells}

Higher concentrations of all the lactobacillus strains displayed greater adherence to $\mathrm{CaCo}-2$ cells (Table 5).

\subsection{Incubation Time Affected Lactobacillus Adherence to CaCo-2 Cells}

A $24 \mathrm{~h}$ incubation time encouraged better lactobacillus adherence to $\mathrm{CaCo}-2$ cells compared to an incubation time of $3 \mathrm{~h}$ (Table 6).

\subsection{Transmission Electron Microscopy Results}

Lactobacillus adheres to CaCo-cells; the cellularity of 


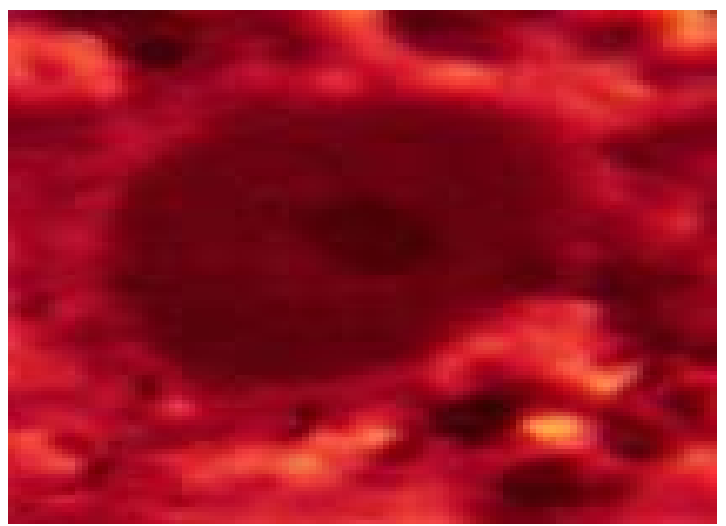

Figure 2. Lactobacillus can hardly adhere to MDCK cell.

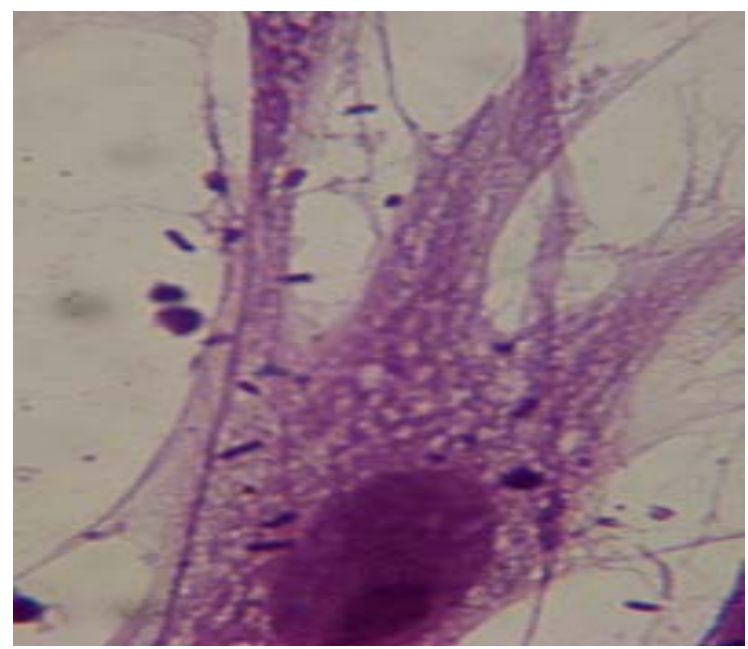

Figure 3. Lactobacillus can adhere to CEF cell.

Table 2. The number of different lactobacillus individual plants adhere to CEF cell.

\begin{tabular}{ccc}
\hline Individual plants & Source & $\begin{array}{c}\text { Level of lactobacillus } \\
\text { adhere to CEF cell }\end{array}$ \\
\hline $\mathrm{SDnB}_{1}$ & $\begin{array}{c}\text { SPF chick Glandular } \\
\text { stomach }\end{array}$ & $7.20 \pm 0.53^{\mathrm{a}}$ \\
$\mathrm{SDnA}_{3}$ & $\begin{array}{c}\text { SPF chick crop } \\
\text { SPF chick }\end{array}$ & $8.40 \pm 0.67^{\mathrm{a}}$ \\
$\mathrm{SDnC}_{1}$ & \begin{tabular}{c} 
Small intestine \\
\hline
\end{tabular}
\end{tabular}

$\overline{\text { a,b values within column with different superscripts differ significantly }(\mathrm{p}<}$ $0.05)$.

Table 3. Effect of varying incubation time on the number of lactobacillus individual plants adhering to CEF cells.

\begin{tabular}{cc}
\hline $\begin{array}{c}\text { Lactobacillus } \\
\text { Strains SDnE } \\
\text { incubation time (d) }\end{array}$ & $\begin{array}{c}\text { Level of lactobacillus adhere } \\
\text { to CEF cell (entries/cell) }\end{array}$ \\
\hline 2 & $25.40 \pm 1.78^{\mathrm{a}}$ \\
4 & $16.70 \pm 1.83^{\mathrm{b}}$ \\
\hline
\end{tabular}

$\overline{\mathrm{a}, \mathrm{b}}$ values within column with different superscripts differ significantly $(\mathrm{p}<$ $0.05)$.
Table 4. Effect of altering incubation time on the number of lactobacillus $\mathrm{SDnB}_{7}$ individual plants adherence to $\mathrm{CaCo}-2$ cells.

\begin{tabular}{cc}
\hline $\begin{array}{c}\text { Lactobacillus } \mathrm{SDnB}_{7} \\
\text { incubation time (d) }\end{array}$ & $\begin{array}{c}\text { Level of lactobacillus adhere to } \\
\text { CaCo-2 cell (entries/cell) }\end{array}$ \\
\hline 2 & $20.00 \pm 1.46^{\mathrm{a}}$ \\
4 & $10.70 \pm 0.99^{\mathrm{b}}$ \\
\hline
\end{tabular}

a,b values within column with different superscripts differ significantly $(\mathrm{p}<$ $0.05)$.

Table 5. Effect of different concentrations on the number of lactobacillus individual plants adhering to $\mathrm{CaCo}-2$ cells.

\begin{tabular}{cc}
\hline $\begin{array}{c}\text { Different concentration } \\
\left(10^{8} \text { bacteria/ml }\right)\end{array}$ & $\begin{array}{c}\text { Level of lactobacillus adhere to } \\
\text { CaCo-2 cell (entries/cell) }\end{array}$ \\
\hline 1 & $20.20 \pm 1.70^{\mathrm{a}}$ \\
0.1 & $13.70 \pm 0.86^{\mathrm{b}}$ \\
0.01 & $10.00 \pm 0.97^{\mathrm{c}}$ \\
0.001 & $6.90 \pm 0.74^{\mathrm{d}}$ \\
0.0001 & $3.30 \pm 0.60^{\mathrm{e}}$ \\
\hline $\mathrm{a}, \mathrm{b}, \mathrm{c}, \mathrm{de}, \mathrm{values}$ within column with different superscripts differ significantly $(\mathrm{p}$ \\
$<0.05)$.
\end{tabular}

Table 6. Effect of different incubation time on the number of lactobacillus individual plants SDn $\mathrm{E}_{1}$ adherence to $\mathrm{CaCo}-2$ cells.

\begin{tabular}{cc}
\hline Action time (h) & $\begin{array}{c}\text { Level of lactobacillus adhering } \\
\text { to CaCo-2 cells (entries/cell) }\end{array}$ \\
\hline 3 & $15.10 \pm 1.49^{\mathrm{a}}$ \\
24 & $25.40 \pm 1.78^{\mathrm{b}}$ \\
\hline
\end{tabular}
a,b values within column with different superscripts differ significantly $(\mathrm{p}<$
$0.05)$.

the junction between $\mathrm{CaCo}-2$ cells and lactobacillus was preserved (Figure 4).

\section{DISCUSSION}

The human gastrointestinal tract is colonized by a variety of gram-positive and gram-negative organisms including bacteria belonging to the lactobacillus genus. The human $\mathrm{CaCo}-2$ cell line has proven to be one of the best model systems for studying interactions between bacterial cells and intestinal epithelial cells [14].

We investigated the adherence of lactobacillus species to $\mathrm{CaCo}-2$ cells quantitatively. The two methods we used to calculate the number of lactobacillus adhering to intestinal epithelial cells included: counting and see.fore is directive use numerical value and post by subjective imagination connect them can precise to response adhesion effect.

We found that lactobacillus have the ability to adhere to intestinal epithelial cells and CEF cells but adhestion to MDCK cells was minimal. This observation is a clear example of host-specificity that until now, had not been 


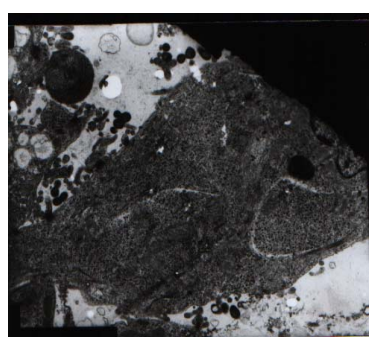

(a)

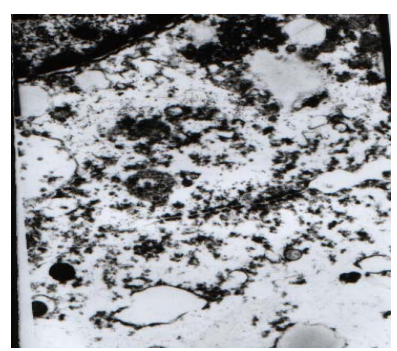

(c)

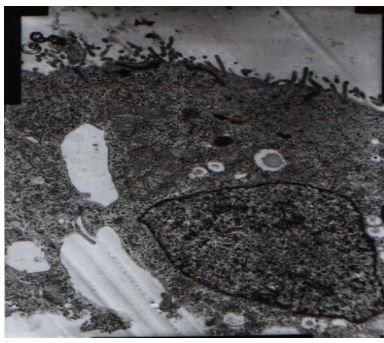

(b)

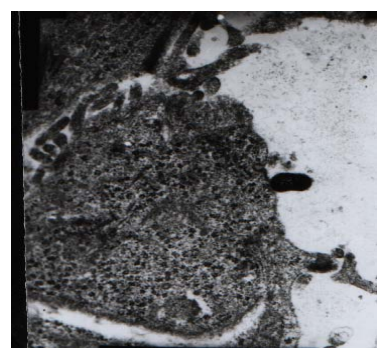

(d)
Figure 4. Results of transmission electron microscopy reveal that (respective magnifications: $7500 \times, 7500 \times, 15 \mathrm{~K} \times$ and 20 $\mathrm{K} \times$ ). (a), (d): Cellularity of the junction between $\mathrm{CaCo}-2$ cells and lactobacillus is preserved; (b): The thalli fabric remains intact; (c): Two-cell connection, cell structure is unaffected.

reported. Intestinal epithelial cells are tumor derived and for this reason, we also incubated primary intestinal epithelial cells from 10 SPF chicken embryos. The adhesion effect was very similar to that seen in the tumorderived cell line.

Incubation time and concentration have a significant effect on lactobacillus adhesion. We demonstrated that incubation for $2 \mathrm{~d}$ at $37^{\circ} \mathrm{C}$ and a $10^{8}$ cells $/ \mathrm{mL}$ bacterial concentration enhanced adhestion ability. This culture conditions will be useful for future adhesion experiments.

\section{ACKNOWLEDGEMENTS}

This work was supported by the Shandong agriculture university microbiology teaching and researching room. We thank the cell bank of china science college Shanghai that provided us with $\mathrm{CaCo}-2$ cells (intestinal epithelial cells); medical science college of Beijing that provided us with MDCK cells; and D. guo (service Microscopie Electronique, Shandong Agriculture University) for technical assistance during the electron microscopy study. This work is supported by the ministry of Agriculture of China: the earmarked fund for Modern Agroindustry Technology Research System of China.

\section{REFERENCES}

[1] Adlerbertti, I., Ahrne, S., Johansson, M.L., Molin, G., Hanson, L.A. and Wold, A.E. (1996) A mannose-specific adherence mechanism in Lactobacillus plantarum conferring binding to the human colonic cell line HT-29. Ap- plied and Environmental Microbiology, 62, 2244-2251.

[2] Bernet, M.-F., Brassart, D., Neeser, J.-R. and Servin, A.L. (1993) Adhesin of human bifidobacterial strains to cultured human intestinal epithelial cells and in hibition of enteropath-ogen cell interactions. Applied and Environmental Microbiology, 59, 4121-4128.

[3] Barrow. P.A., Brooker, B.E. and Fuller, R. (1980) The attachment of bacteria to the gastric epithelium of the pig and its importance in the microecology of the intestinal. Journal of Applied Bacteriology, 48, 147-154. doi:10.1111/j.1365-2672.1980.tb05216.x

[4] Bernet, M.F., Brassart, D. and Neeser, J.R. (1994) ServinAL. Lactobacillus acidopHilus LA 1 binds to Cultured intestinal cell Lines and inhibits cell attachment cell invasion by enterovirulen. Bacteria Gut, 35, 483-489.

[5] Fontaine, I.F., Aissi, E.A. and Bouquelet, S.J.L. (1994) In vitro binding of Bifidobaeterium bifidum DSM 20082 to mucosal glycoproteins and hemagghutinating activity. Current Microbiology, 28, 325-330.

[6] Fuller, R. and Turvey, A. (1971) Bacteria associated with the intestinal wall of the fowl (Gallus domesticus). Journal of Applied Bacteriology, 34, 617-622. doi:10.1111/j.1365-2672.1971.tb02325.x

[7] Flint, S.H., Brooks, J.D. and Bremer, P.J. (1997) The influence of cell surface properties of thermophilic streptococci on attachment to stainless steel. Journal of Applied Microbiology, 83, 508-517. doi:10.1046/j.1365-2672.1997.00264.x

[8] Fuller, R. (1977) The importance of lactobacilli in maintaining normal microbial balance in the crop. British Poultry Science, 18, 85-94.

[9] Gusils, C., Palacios, J. and Gonzalez, S. (1999) Lectinlike protein fractions in lactic acid bacteria isolated from chickens. Biological and Pharmaceutical Bulletin, 22, 11-15.

[10] Gusils, C., Cuozzo, S. and Sesma, F. (2002) Examination of adhesive determinants in three species of lactobacillus isolated from chicken. Canadian Journal of Microbiology, 48, 34-42.

[11] Edelman, S., Westerlund-Wikstrom, B., et al. (2002) In vitro adhesion specificity of indigenous lactobacilli within the avian intestinal tract. Applied and Environmental Microbiology, 68, 5155-5159. doi:10.1128/AEM.68.10.5155-5159.2002

[12] Mack, D.R., Michail, S., Wei, S. and Mcdougall, L.C. (1999) Probiotics inbibit enterropathogenic E. coli adherence in vitro by inducing intestinal mucin gene expression. American Journal of Physiology, 276, G941-G950.

[13] Rinkinen, M., Westermarck, E., Salminens, O.U. and Wehand, A.C. (2003) Absence of hose specificity for in vitro adhesion of probiotic lactic acid bacteria to intestinal mucus. Veterinary Microbiology, 97, 55-61. doi:10.1016/S0378-1135(03)00183-4

[14] Greene Jeffreyd and Toddr Klaenhammer. (1994) Factors involved in adherence of lactobacilli to human $\mathrm{CaCo}-2$ cells. Applied and Environmental Microbiology, 60, 4487 4494. 